\title{
UPAYA KONSERVASI DAN REHABILITASI PADA KAWASAN TANAH TIMBUL (AANSLIBBING): STUDI KASUS PESISIR UTARA CIREBON TIMUR
}

Oleh: Millary Agung Widiawaty

Kabupaten Cirebon merupakan salah satu region administratif di Provinsi Jawa Barat. Wilayah ini terbagi atas Cirebon Barat dan Cirebon Timur yang mana kedua wilayah tersebut dipisahkan oleh Kota Cirebon (Anshari., dkk, 2017). Cirebon Timur berbatasan langsung dengan Laut Jawa di bagian utara dan membentuk kawasan pesisir yang meliputi Kecamatan Mundu, Kecamatan Astanajapura, Kecamatan Pangenan, Kecamatan Gebang, dan Kecamatan Losari.

Pesisir utara Cirebon Timur merupakan muara bagi beberapa sungai dari DAS Pantura - Ciayu $\left(1820 \mathrm{~km}^{2}\right)$ dan DAS Cisanggarung $\left(1325 \mathrm{~km}^{2}\right)$. Melimpahnya material fluvial yang ditambah dengan adanya pertemuan arus sepanjang pantai (longshore current) menyebabkan terakumulasinya sedimen dari sungai-sungai tersebut (Faturachman., dkk, 2004; Warman, 2015). Proses sedimentasi tersebut memicu terbentuknya tanah timbul. Pada Peraturan Pemerintah Nomor 16 Tahun 2004 tentang Penatagunaan Tanah didefinisikan bahwa tanah timbul adalah daratan yang terbentuk secara alami maupun buatan karena proses pengendapan di sungai, danau, pantai dan atau pulau timbul. Tanah timbul menyebabkan penambahan luas daratan ke arah perairan bila memiliki laju akresi yang lebih tinggi dibandingkan proses abrasi.

\section{A. Keberadaan Tanah Timbul Pesisir Cirebon Timur}

Pengamatan tanah timbul dapat melalui pemanfaatan citra penginderaan jauh. Analisis perubahan garis pantai akibat akresi dan abrasi dilakukam melalui komposit citra Landsat-7 TM tahun 1999, Landsat-5 TM tahun 2008 dan Landsat8 OLI tahun 2018. Dari hasil overlay citra satelit tersebut diketahui bahwa perubahan garis pantai akibat abrasi dan akresi terjadi di beberapa kecamatan pesisir utara Cirebon Timur. Fenomena abrasi dominan terjadi di Kecamatan Mundu, sedangkan Akresi dapat ditemui pada hampir semua kecamatan yang berada di pesisir utara Cirebon Timur seperti Kecamatan Gebang dan Kecamatan 
Losari. Sungai yang paling berpengaruh terhadap proses sedimentasi di wilayah ini yakni Ci Temu, Kali Pasung, Ci Beres, dan Kali Bangka.

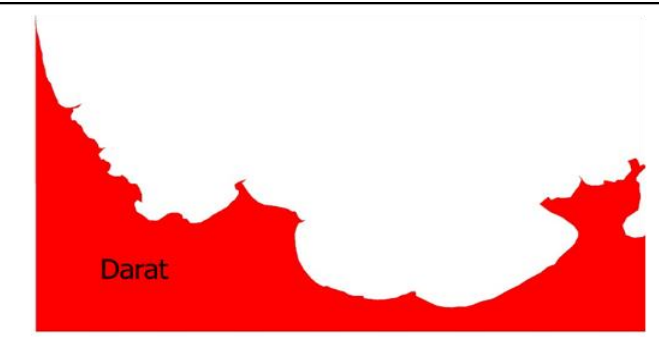

(a) Landsat-7 TM Tahun 1999

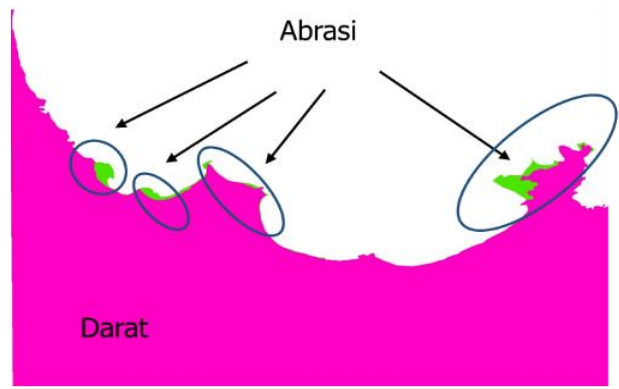

(a) Hasil overlay digitasi citra tahun 2008 dengan 1999

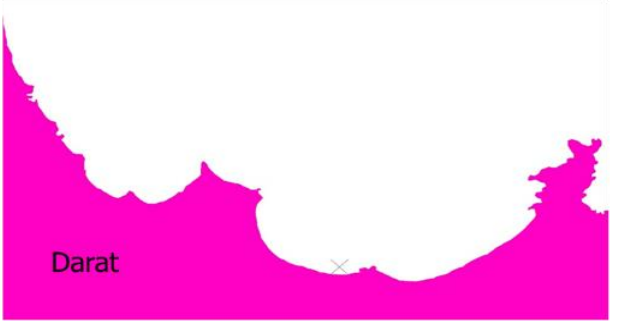

(b) Landsat-5 TM Tahun 2008

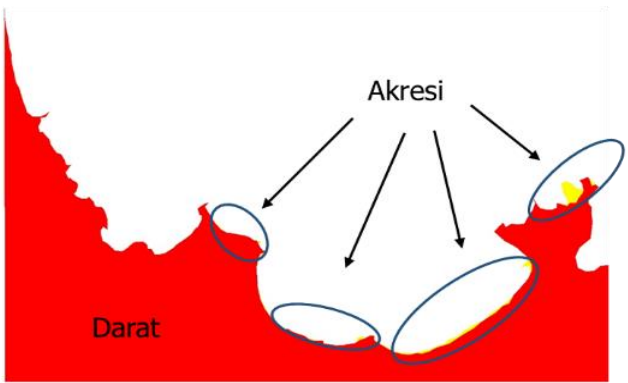

(b) Hasil overlay digitasi citra tahun 1999 dengan 2008

Gambar 13: Abrasi dan Akresi Tahun 1999 - 2008

Sumber: Analisis Penulis, 2018

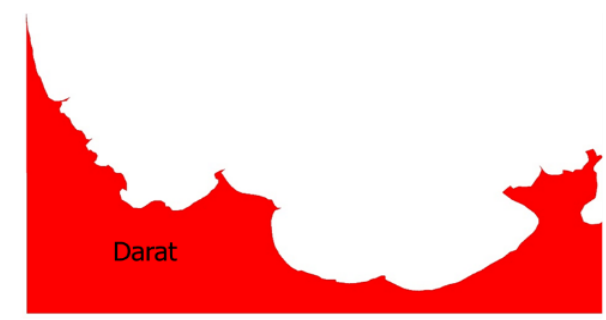

(a) Landsat-7 TM Tahun 1999

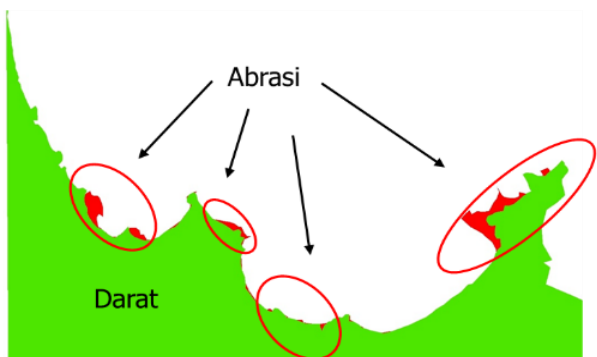

(a) Hasil overlay digitasi citra tahun 1999 dengan 2018

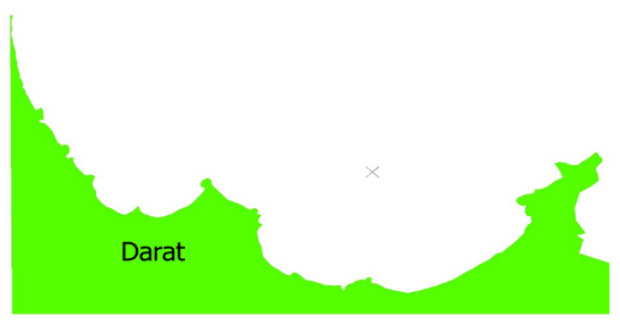

(b) Landsat-8 OLI Tahun 2018

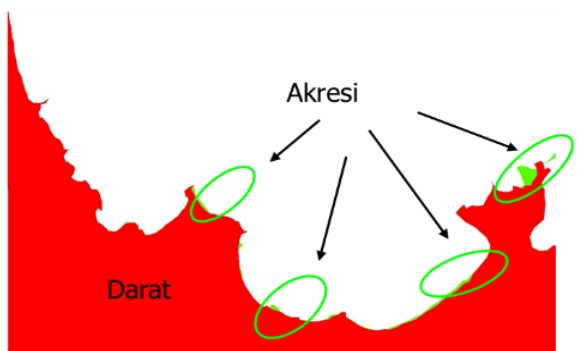

(b) Hasil overlay digitasi citra tahun 2018 dengan 1999

Gambar 14: Abrasi dan Akresi Tahun 1999 - 2018

Sumber: Analisis Penulis, 2018

Akresi terjadi akibat proses pengendapan yang menyebabkan terbentuknya tanah timbul serta mengakibatkan bertambahnya garis pantai. Akresi di Cirebon Timur umum terjadi pada pantai yang membentuk teluk, hal ini disebabkan adanya 
pemuasatan dan perputaran arus. Selain itu, teluk juga dikenal sebagai wilayah perairan laut yang sangat tenang dan sesuai untuk terakumulasinya material sedimen. Hasil akhir dari proses akresi ini dikenal sebagai tanah timbul.

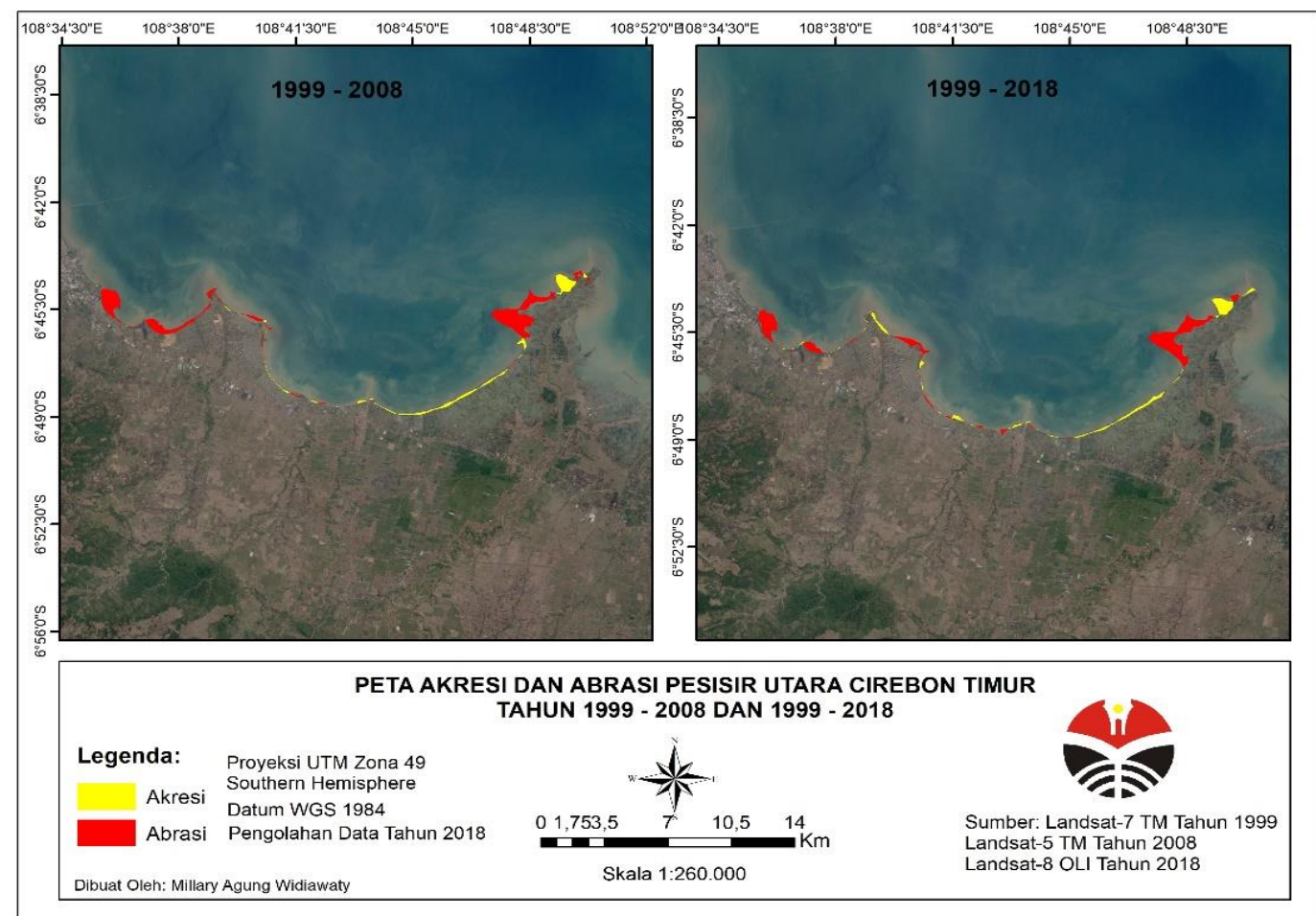

Gambar 15. Peta Citra Abrasi dan Akresi Tahun 1999 - 2008 dan 1999 - 2018 Sumber: Analisis Penulis, 2018

Luas tanah timbul akibat akresi dari tahun 1999 hingga tahun 2008 yakni $1,802 \mathrm{~km}^{2}$ dan luas lahan akibat abrasi yakni $5,887 \mathrm{~km}^{2}$. Sedangkan luas tanah timbul akibat akresi dari tahun 1999 hingga tahun 2018 yakni 2,029 km² serta luas lahan akibat abrasi yakni 5,341 $\mathrm{km}^{2}$.

\section{B. Potensi Tanah Timbul Pesisir Cirebon Timur}

\section{Potensi Penguasaan Lahan}

Berdasarkan Peraturan Daerah Provinsi Jawa Barat Nomor 6 Tahun 2011 bahwa secara alami tanah timbul dikuasai oleh negara di bawah pengawasan Gubernur yang merupakan turunan dari Pasal 33 UUD RI 1945. Selanjutnya aturan mengenai tanah timbul juga ditetapkan oleh pemerintah daerah pada tingkat kota / kabupaten (Noorrahmah., dkk, 2014). Dengan demikian pemerintah dapat memanfaatkan potensi ini sebagai cadangan lahan di masa yang akan datang. 


\section{Potensi Pemanfaatan Lahan}

Keberadaan tanah timbul akan membentuk ekosistem pesisir berupa hutan mangrove. Keberadaan tanah timbul dapat dimanfaatkan oleh pemerintah maupun masyarakat setempat untuk berbagai kepentingan melalui pengawasan gubernur. Bagi masyarakat pesisir, keberadaan tanah timbul dapat dimanfaatkan untuk mendirikan lahan terbangun sebagai tempat bermukim atau melakukan aktivitas ekonomi seperti tambak ikan, udang, garam, pelabuhan/ dermaga, dan pariwisata bahari.

\section{Tantangan Keberadaan Tanah Timbul Pesisir Cirebon Timur}

\section{Legalitas Kepemilikan Lahan}

Ditinjau dari berbagai aspek ekonomi dan sosial, keberadaan tanah timbul seringkali menyebabkan banyak persoalan. Berdasarkan hasil survey tahun 2018 di sepanjang pesisir Cirebon Timur, lahan di wilayah tersebut dimanfaatkan oleh masyarakat setempat sebagai permukiman illegal tanpa IMB (Izin Mendirikan Bangunan) atau klaim sepihak melalui pemasangan tanda. Mereka umumnya berpandangan bahwa tanah timbul memiliki status kepemilikan yang tidak jelas dan berhak untuk diklaim, meskipun secara yuridis keberadaannya dikuasai dan miliki oleh negara.

\section{Kerusakan Ekosistem Pesisir}

Bila ditinjau dari aspek lingkungan fisiknya, ekosistem sekitar pesisir di Cirebon Timur yang memiliki tanah timbul umumnya mengalami penurunan daya dukung lingkungan. Aktivitas masyarakat yang tidak bijak menimbulkan banyak permasalahan. Mangrove yang semestinya berperan sebagai konservator pesisir, ditebang oleh masyarakat guna memperoleh lahan tambak, pemukiman, dan kayu bakar sehingga menyebabkan kerusakan yang cukup serius. Berkurangnya mangrove akan mendorong proses intrusi air laut berlangsung dengan cepat yang berdampak pada penurunan kualitas air tawar. Intrusi menyebabkan pula keberadaan biota di sekitar mangrove terus berkurang populasinya akibat perubahan salinitas. 


\section{Bentuk Konservasi dan Rehabilitasi Tanah Timbul Pesisir Utara Cirebon Timur}

Tanah timbul memiliki peranan strategis bagi masyarakat Cirebon Timur bila pengelolaannya dilakukan dengan bijak baik secara langsung maupun tidak langsung bagi manusia (Supriharyono, 2002). Untuk dapat merealisasikannya, pemerintah Kabupeten Cirebon beserta masyarakat setempat perlu mengambil langkah konservasi dan rehabilitasi tanah timbul diantaranya dengan melakukan pengangkutan dan pembersihan, restorasi mangrove dan menetapkannya kawasan lindung, serta melakukan penataan kawasan hulu (up land management) agar laju akresi tetap terkontrol (Susetyaningsih, 2012; Noorrahmah., dkk, 2014).

\section{Pengangkutan dan Pembersihan}

Wilayah pesisir utara Cirebon Timur merupakan muara sungai dari dua DAS yang berada di Kabupaten Cirebon, akibatnya proses sedimentasi yang membentuk tanah timbul berlangsung dengan cepat. Aliran air sungai membawa material halus berupa lumpur dan material kasar yang berupa sampah rumah tangga. Material berupa sampah dapat menyebabkan kumuhnya dan menyebabkan pencemaran lingkungan sehingga menurunkan daya dukung tanah timbul.

Sedimentasi menyebabkan kekeruhan air meningkat sehingga dapat menghalangi cahaya matahari untuk masuk ke dalam air dan mengganggu kehidupan organisme, contohnya ekosistem lamun (seagrass) beserta biota di dalamnya akan terganggu pertumbuhannya bila kekurangan intensitas cahaya matahari. Dampak lainnya yakni material sedimen yang berasal dari lahan pertanian umumnya mengandung nitrogen dan fosfat yang tinggi dapat menyebabkan masalah eutrofikasi. Terjadinya eutrofikasi dapat diamati secara langsung dari melonjaknya populasi tumbuhan air secara cepat (Dahuri., dkk, 2013).

Upaya untuk mengurangi material berat serta memulihkan ekosistem yang terganggu karena bertambahnya kekeruhan air akibat material sedimen dari sungai dapat dilakukan dengan pembersihan sampah secara rutin oleh masyarakat sekitar maupun oleh pemerintah dengan mengerahkan sejumlah alat berat untuk kegiatan pengerukkan. Selain itu, penyediaan tempat pembuangan 
akhir yang dikelola secara berkala juga dapat mencegah masyarakat untuk membuang sampah rumah tangga di aliran sungai.

\section{Melakukan Penertiban Sekitar Kawasan Tanah Timbul}

Upaya penertiban sekitar kawasan tanah timbul dilakukan guna terciptanya lingkungan yang bersih terbebas dari permukiman kumuh. Pemerintah dapat memberi pemahaman pada masyarakat melalui sosialisasi yang dikemas secara apik dengan memperhatikan kondisi masyarakat setempat. Di beberapa titik di Cirebon Timur seperti di muara Kali Bangka (Kecamatan Pangenan), kawasan mangrove dan muara sungai telah diberikan rambu atau tanda zona lahan dari Kementereian Lingkungan Hidup dan Kehutanan (KLHK). Selain itu, penertiban juga dapat dilakukan dengan mencegah masyarakat nelayan membangun dermaga kapal atau perahu di sekitar muara sungai yang berpotensi terjadinya tanah timbul.

\section{Restorasi Mangrove}

Permasalahan akeasi akibat sedimentasi memerlukan perhatian ekstra dari tiap stakeholders, salah satunya melalui kegiatan penghijauan area muara suangai dan tanah timbul dengan vegetasi mangrove. Restorasi mangrove dapat menjadi alternatif pilihan dalam mengatasi kerusakan di sekitar tanah timbul. Ekosistem mangrove memiliki berbagai fungsi baik secara ekologis, maupun sosial dan ekonomi, salah satunya berfungsi sebagai penjebak sedimen dari sungai menuju pesisir, sehingga berbagai pihak memberi perhatian lebih untuk mengembalikan fungsi ekosistem ini melalui kegiatan restorasi (Setiady dan Usman, 2008).

Restorasi dapat diartikan sebagai proses mengubah secara sengaja keadaaan lingkungan suatu lokasi guna menetapkan suatu ekosistem yang bersifat tertentu, asli, dan bersejarah. Kegiatan ini bertujuan untuk mengembalikan struktur, fungsi, keanekragaman dan dinamika suatu ekosistem yang dituju (Primack., dkk, 1998; Setyawan., dkk, 2003). Basyuni (2002) menerangkan bahwa aspek-aspek yang dapat dipertimbangkan dalam merestorasi ekosistem mangrove yang rusak antara lain sebagai berikut:

a. Eksploitasi yang berlebihan atau penebangan hutan mangrove terus menerus, 
b. Masalah erosi di wilayah estuaria,

c. Pengurangan produktivitas perikanan dan biota lainnya,

d. Konversi hutan mangrove menjadi tambak,

e. Penciptaan fasilitas umum dan dijadikan permukiman penduduk.

Kegiatan restorasi mangrove memiliki sejumlah langkah yang harus dipahami sebagai bagian dari operasionalnya. Berdasarkan Mangrove Action Project Indonesia (2007), setidaknya terdapat lima langkah dalam merestorasi mangrove, yakni sebagai berikut.

a. Memahami autekologi (sifat ekologi) masing-masing spesies mangrove, khususnya pola reproduksi, distribusi bibit serta keberhasilan pembentukan bibit,

b. Memahami pola hidrologis yang mengatur distribusi dan keberhasilan pembentukan serta pertumbuhan sepesies mangrove yang ditargetkan,

c. Memperkirakan perubahan lingkungan mangrove asli yang menghalangi pertumbuhan alami mangrove,

d. Desain program rehabilitasi dan restorasi untuk memperbaiki kondisi hidrologis,

e. Melakukan tahap penamanan mangrove.

Rehabilitasi ekosistem mangrove sebagai benteng utama pencegah abrasi dan akresi sering mendapat berbagai masalah terkait efektifitas dan efisiensi dalam penanaman, seperti banyaknya bibit mangrove yang gagal tumbuh akibat hanyut terbawa arus, jarak penanaman pohon yang tidak sesuai, penggunaan berbagai penyangga dalam penanman, dan diperlukan berbagai alat pemecah ombak (Tarika dalam National Geographic Indonesia, 2015). Oleh karena itu, penanaman mangrove sebaiknya dilakukan secara terpadu dan terencana.

Salah satu inovasi yang dapat diterapkan dalam bidang konservasi lingkungan terhadap abrasi di zona litoral secara vegetatif adalah TetraPOT mangrove. TetraPOT merupakan metode pertahanan pantai dari ancaman abrasi yang ramah lingkungan, karena terbuat dari komposit bahan organik, pasir, dan semen (Lee dan Lee, 2016). TetraPOT digunakan sebagai media tumbuh mangrove dapat mengatur jarak penanaman antar bibit mangrove. Pada awal 
penanaman, pertumbuhan mangrove berlangsung secara internal di dalam tertraPOT, hingga dalam jangka waktu tertentu akar-akar mangrove akan keluar dari TetraPOT dan saling terjalin satu sama lain membentuk pertahanan pantai (Lee dan Lee, 2016).

\section{Menetapkan Tanah Timbul sebagai Kawasan Lindung}

Tanah timbul diharapkan mampu menjadi kawasan lindung bagi wilayah pesisir guna mendukung pulihnya ekosistem sebagaimana termuat dalam Peraturan Daerah Provinsi Jawa Barat Nomor 9 Tahun 2012 Tentang Pengelolaan Wilayah Pesisir dan Pulau-Pulau Kecil dalam pasal 16 Ayat (1). Terwujudnya kawasan lindung di wilayah tanah timbul hanya dapat terjadi apabila pemerintah membuat ketegasan peraturan status penguasaan tanah timbul.

Pengaturan mengenai peruntukan dan penggunaan tanah timbul Kota Cirebon akan mengacu pada pasal 31 sampai dengan pasal 33. Pasal 31 (1) menyebutkan bahwa ketertiban penguasaan tanah timbul oleh pihak tertentu dan untuk menjaga tidak terjadinya kerusakan pantai, di dalam menetapkan peruntukan dan penggunaan tanah timbul ditetapkan jalur konservasi berupa greenbelt yang panjangnya antara 100 - 400 meter dihitung dari titik surut terendah pantai yang bersangkutan. Sementara itu pasal 32 menyebutkan bahwa penggunaan tanah timbul di luar jalur konservasi pantai (greenbelt), ditetapkan berdasarkan skala prioritas diantaranya kehutanan, perikanan, pertanian, peternakan dan, pariwisata.

\section{Penataan Kawasan Hulu (Up Land Management)}

Daerah Aliran Sungai (DAS) merupakan suatu sistem kompleks yang dibangun atas sistem fisik (physical systems), sistem biologis (biological systems) dan sistem manusia (human systems) yang saling terkait dan berhubungan satu sama lainnya. Sistem ini membentuk kesatuan ekologis yang dari hulu hingga hilir sungai (muara). Apabila terjadi ketidakseimbangan akibat kerusakan yang terjadi pada salah satu bagian nya, dampak yang ditimbulkan akan berpengaruh pada semua bagian dari sistem DAS (Susetyaningsih, 2012).

Kerusakan yang terjadi pada bagian hulu akibat berkurangnya tutupan lahan menyebabkan terjadinya erosi dan memicu terjadinya sedimentasi. 
Pembangunan yang pesat terjadi di hulu DAS menjadi penyebab besarnya konversi lahan hutan di daerah hulu menjadi pertanian, perkebunan, dan permukiman (Direktorat Jenderal Penataan Ruang, 2010). Kerusakan yang terjadi perlu direhabilitasi melalui penataan kembali kawasan hulu. Penataan kawasan hulu diharapkan dapat berfungsi sebagai penadah air dan penahan sedimentasi dari hulu menuju hilir sungai (muara).

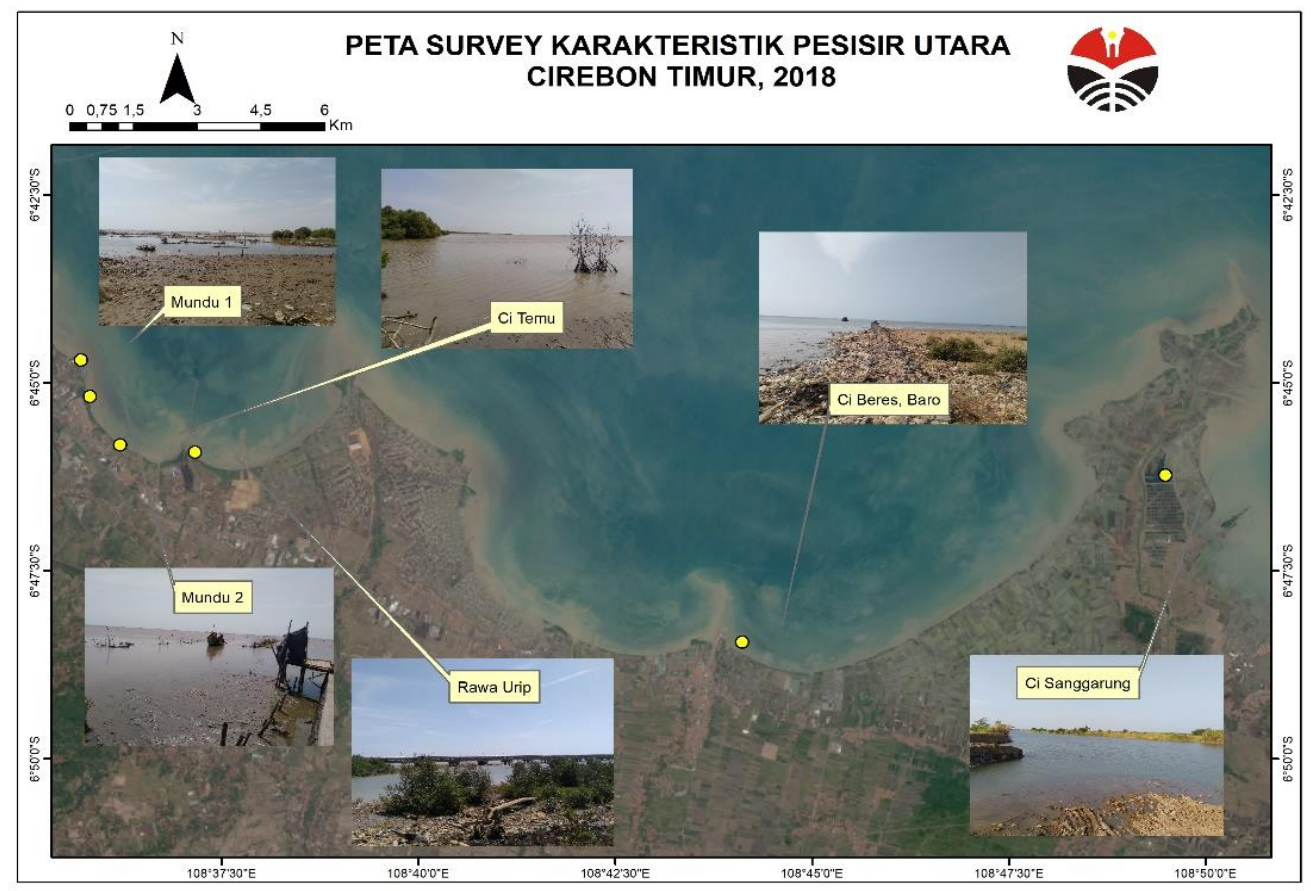

Gambar 16: Peta Survey Karakteristik Pesisir Utara Cirebon Timur Sumber: Analisis Penulis, 2018

\section{Referensi:}

Anshari., dkk. (2017). "Kajian Etnosemantik dalam Toponimi Wilayah Kabupaten Cirebon dan Kota Cirebon". Prosiding Seminar Internasional Leksikologi dan Leksikografi, hlm. 64 - 69.

Basyuni, M. (2002). "Panduan Restorasi Hutan Mangrove yang Rusak (Degrated)". Karya Tulis Ilmiah Fakultas Pertanian Program Ilmu Kehutanan Universitas Sumatera Utara, hlm. 1-14.

Dahuri, R., dkk. (2013). Pengelolaan Sumber Daya Pesisir dan Lautan secara Terpadu. Jakarta: Balai Pustaka. 
Direktorat Jenderal Penataan Ruang. (2010). Peningkatan Penataan Kawasan DAS Bengawan Solo. Laporan Akhir. Direktorat Jenderal Penataan Ruang. Jakarta.

Faturachman, A., dkk. (2004). "Pendangkalan Pelabuhan Cirebon dan Astanajapura Akibat Proses Sedimentasi (Berdasarkan Data Seismik Pantul Dangkal dan Pemboran Inti)". Jurnal Geologi Kelautan, Vol. 2 (1), hlm. 15 - 23.

Lee, S. H dan Lee, W. K. (2016). TetraPOT. Tersedia [dalam Jaringan] http://shenghunglee.wixsite.com/design/TetraPOT . Diakses pada 9 Agustus 2018

Mangrove Action Project Indonesia. (2007). "Restorasi Hutan Bakau Berwawasan Ekologi”. Artikel Petunjuk Umum Restorasi Habitat Bakaui, hlm. 1-10.

National Geographic Indonesia. (2015). Ikhtiar di Pesisir Karangsong. Tersedia [dalam Jaringan] http://nationalgeographic.co.id/berita/2015/12/ikhtiar-dipesisirkarangsong/1 . Diakses pada 9 Agustus 2018.

Noorrahmah, N., Munawir, R dan Almarta, F. (2014). Tanah Timbul di Kota Cirebon Peluang \& Tantangan. Tugas Karya Tulis Kelompok Pengantar Perencanaan Wilayah dan Kota ITB.

Primack, R.B., J. Supriatna, M. Indrawan dan Kramadibrata, P. (1998). Biologi Konservasi. Jakarta: Yayasan Obor.

Setiady, D dan Usman, E. (2008). "Majunya Garis Pantai yang Diakibatkan oleh Proses Sedimentasi di Sepanjang Pantai Perairan Kabupaten Rembang”. Jurnal Geologi Kelautan. Vol. 6 (3), hlm. 146 - 153.

Setyawan, A, D., Winarno, K dan Purnama, P. C. (2003). "Ekosistem Mangrove di Jawa: Restorasi”. Jurnal Biodiversitas. Vol. 5 (2), hlm. 105 - 118.

Supriharyono. (2002). Pelestarian dan Pengelolaan Sumber Daya Alam di Wilayah Pesisir Tropis (Ed. 2).Jakarta: Gramedia Pustaka Utama.

Susetyaningsih, A. (2012). "Pengaturan Penggunaan Lahan di Daerah Hulu DAS Cimanuk sebagai Upaya Optimalisasi Pemanfaatan Sumberdaya Air”. Jurnal Konstruksi. Vol. 10 (1), hlm. 1 - 8.

Warman, G. (2015). Studi Geologi dalam Perencanaan dan Penentuan Lokasi Pembangunan Pelimpah Darurat Bendungan Jatigede, Jawa Barat. Skripsi Teknik Geologi UGM. 